Article

\title{
Foreign Direct Investment Inflows and Financial Development in Central and Eastern European Union Countries: A Panel Cointegration and Causality
}

\author{
Yilmaz Bayar ${ }^{1}$ and Marius Dan Gavriletea ${ }^{2, *(\mathbb{D})}$ \\ 1 Faculty of Economics and Administrative Sciences, Usak University, 64100 Usak, Turkey; \\ yilmaz.bayar@usak.edu.tr \\ 2 Faculty of Business, Department of Business, Babeş-Bolyai University, 400084 Cluj-Napoca, Romania \\ * Correspondence: dan.gavriletea@tbs.ubbcluj.ro; Tel.: +40-0264-599-170
}

Received: 23 March 2018; Accepted: 24 May 2018; Published: 29 May 2018

\begin{abstract}
Foreign direct investment (FDI) inflows have increased considerably in the globalized world as of the mid-1980s. The main objective of this research is to analyze interactions between FDI inflows and financial sector development in Central and Eastern European Union countries between 1996 and 2015 with panel data analysis. Our findings reveal that there is no cointegrating relationship among FDI inflows, investments of foreign portfolio, and the development of financial sectors, but there is a one-way causality from development of financial sectors to FDI inflows over the short run.
\end{abstract}

Keywords: financial development; foreign direct investment inflows; foreign equity investments; panel data analysis

JEL Classification: C22; F23; G10; O16

\section{Introduction}

Foreign direct investment (FDI) is a versatile concept based on the fact that it plays an important role in a country's development, and there are many aspects related to this issue that need to be carefully examined.

Firstly, although the positive effects of FDI are multiple, we will emphasize the fact that it is also a source of negative impacts (Aitken and Harrison 1999; Kathuria 2000; Smarzynska Javorcik 2004; Forte and Moura 2010; Žilinskè 2010; Gerschewski 2013). There is evidence that:

- productivity of domestic firms decrease when FDI increases (Aitken and Harrison 1999; Kathuria 2000; Gerschewski 2013);

- unemployment can increase based on the fact that foreign companies using new and modern technologies will need less employees compared to similar domestic companies (Forte and Moura 2010; Žilinske 2010) and that they are looking to use local cheap resources (Žilinskè 2010);

- $\quad$ and that knowledge transfer from multinational enterprises is usually directed to local suppliers or customers, and prevention of technology leak to local competitors is achieved usually through intellectual property protection (Smarzynska Javorcik 2004; Gerschewski 2013).

Secondly, even though there is evidence that FDI positively influences economic growth, there is no clear evidence regarding who benefits more (host countries or home countries) (Lipsey 2002). 
Thirdly, there is a lack of studies that investigate categories of countries that attract the highest values of FDI (developed countries vs developing countries). Diaconu Maxim (2015) pointed out that for a long period of time, developed countries attracted increasing flows of FDI compared to developing countries; however, the situation changed after the 2008 global financial crisis. Obviously, besides global crises, there are other factors that can change FDI inflows from one country or region to another.

It is also very important to analyze and understand which factors are the major determinants of FDI. The numerous empirical studies that have been conducted to reveal the economic, social, and cultural determinants of FDI have generally focused on economic size and growth, inflation, openness, financial development, tax rates, physical infrastructure, institutional development, economic freedom, religion, distance between countries, and common culture (e.g., see Bayar and Ozel 2014; Saini and Singhania 2018). However, a few studies have focused on the interplay between finance and FDI. In this context, authorities play a major role in developing and implementing strategies that can create an appropriate and favorable environment for FDI.

There are many other aspects that need to be clarified related to issues of FDI. In this study, we focus mainly on the interaction between FDI inflows and financial sector development considering the gap in the related literature, as well as the fact that many studies have investigated the factors mentioned above. In recent years, financial sector development has become a significant economic growth factor together with the acceleration of financial liberalization and the considerable expansion of the global financial sector through the efficient allocation of funds achieved by the easing of risk management, allocation of resources, monitoring managers, mobilizing savings, and easing of output transfers (Levine 1997). In this context, many theoretical and empirical papers have focused on the discovery of factors underlying the development of the financial sector. The conclusions of these studies revealed that institutions, trade openness, legal traditions, and political economy are major factors which promote financial sector development (Law and Habibullah 2009; Huang 2011; Voghouei et al. 2011; Popescu 2014; Cherif and Dreger 2016). Furthermore, globalization processes have led to considerable increases in the flows of FDI and transnational portfolio investments. As a result, global FDI flows reached $\$ 1.76$ trillion in 2015 after a substantial contraction due to recent crises in the world (UNCTAD 2016). In addition, global portfolio equity was approximately \$1.116 trillion in 2014 (World Bank 2016a). Therefore, both FDI and portfolio inflows have become important sources of finance, especially for countries with insufficient capital. However, the increasing frequency and severity of the crises associated with globalization processes have caused significant decreases in foreign capital flows, and interruptions in international capital flows may damage the development of economies.

Consequently, researchers have focused on the finance-growth nexus and the FDI-growth nexus in parallel with these transformations, and they revealed that both financial sector development and FDI inflows have made significant contributions to economic growth through various channels (Adeniyi et al. 2015; Nwaogu and Ryan 2015; Chowdhury 2016; Pradhan et al. 2016). Based on data from eight European developing countries (i.e., Albania, Belarus, Croatia, Latvia, Lithuania, Poland, Romania, and Turkey), Mahmoodi and Mahmoodi (2016) concluded that economic growth can be stimulated by FDI inflows. Simionescu (2016) reached the same conclusion that FDI had a positive impact on economic development using data from EU-28 countries, during the years from 2008-2014.

However, a limited number of studies have been implemented to investigate the interaction between financial sector development and FDI inflows, despite these two variables having the potential to theoretically affect each other. In this context, FDI inflows may affect the development of financial sectors positively by increasing funds in a financial system, but it can also have no influence or a negative impact on the development of a financial sector, as FDI inflows are also an alternative financing instrument, or in other words, a competitor for domestic financial markets (Levine 1997; Desbordes and Wei 2014). Furthermore, a more developed financial system causes a country to experience FDI inflows by providing external finances under better economic conditions for the 
attraction of FDI inflows (Desbordes and Wei 2014). On the other hand, foreign portfolio investments can contribute to the development of financial sectors by providing funds for financial markets through purchases of financial instruments, but considerable withdrawals in the foreign portfolio inflows have the potential to damage financial institutions. However, an improved financial sector can lead to increases in foreign equity flows by providing more financial instruments (Desbordes and Wei 2014). Based on an analysis that focused on Brazil, Russia, India, China, and South Africa, Kaur et al. (2013) reach the conclusion that stock market capitalization and the size of banking sector positively influenced FDI, and they additionally specified that "more domestic credit by the banking sector negatively influences FDI inflows." On the contrary, another study conducted by Aqeel et al. (2004) found that FDI inflows in Pakistan were significantly influenced by the size of domestic credit to the private sector. Consequently, the interaction among FDI inflows, foreign portfolio inflows, and financial development remained ambiguous in theoretical terms.

The main objective of this paper is to analyze the short- and long-run interactions between financial development and FDI inflows using data from a panel of 11 Central and Eastern European Union (CEEU) countries, consisting of Slovenia, Slovak Republic, Romania, Poland, Lithuania, Latvia, Hungary, Estonia, Czech Republic, Croatia, and Bulgaria between the period from 1996-2015. The CEEU countries have transited from closed or relatively closed economies (Estrin 1991; Uvalic 2018) to open market ones as a result of the late 1980s collapse of the Communist Bloc and pursued integration within the European Union (EU).

Decades of communism put their mark on each economic sector and the process of transition from communism to capitalism was a long-term process that involved systemic reforms. Obviously, at the beginning of the 1990s each country had its own level of economic development and adopted different reforms during the transition period which attracted different levels of FDI. Dãian (2012) and Gorbunova et al. (2012) stipulate that starting with the 1990s, European countries in transition faced massive inflows of FDI. This is not surprising taking into consideration that multinational enterprises found a well-educated and cheap labor force there, as well as good infrastructure (Noble et al. 2011). The study conducted by Gorbunova et al. (2012) on 26 former socialist European countries also concluded that FDI inflows were mainly influenced by "specific market and institutional factors", and therefore, in order to attract FDI inflows it was necessary to focus more on institutional factors rather than economic ones. So institutional variables have become relatively more important than economic factors in this sample of countries due to the transformation process.

Integration with the EU, another important stage in CEEU countries' evolution, also forced them to make structural reforms for EU membership. Therefore, CEEU countries have attracted FDI inflows and foreign portfolio investments from developed EU member countries and also from other countries as a result of economic and institutional transformations.

This paper is one of the initial studies on the finance-FDI nexus and is structured as follows. Section 2 is a literature review which provides a brief review of some of the previous representative studies related to this subject. Section 3 provides the data and econometric methodology, and gives an explanation of the data and methods used in this research. Section 4 is an empirical analysis which indicates the empirical results based on selected tests. Finally, the last section presents the main conclusions of this research.

\section{Literature Review}

It is well known that an abundance of FDI in a country generates economic growth (Kurtishi-Kastrati 2013). There are many benefits associated with FDI, including environmental and social improvement, knowledge transfer, employment opportunities, new technologies, and innovations (De Mello 1997; Basu and Guariglia 2007; Kurtishi-Kastrati 2013), and the generation of state budget income (Nistor and Păun 2013). Even these benefits differ from one country to another based on their ability to attract FDI, and it is very important for all countries to see FDI as a source of economic development and modernization. 
Considerable expansion in both foreign capital inflows (i.e., FDI inflows and foreign portfolio investments) and financial sectors have led researchers to discover possible macroeconomic effects of foreign capital inflows and financial development. Empirical studies have generally focused on the FDI and portfolio inflow-growth nexus and the financial development-growth nexus (Eschenbach 2004; Acaravci et al. 2009; Wan 2010; Almfraji and Almsafir 2014; Ahmad et al. 2016). Furthermore, some authors have studied the influence of financial development on the FDI-growth interaction and discovered financial development was a prerequisite for the positive interaction between FDI inflows and growth (Alfaro et al. 2004; Adjasi et al. 2012). However, a limited number of papers have analyzed the interaction between FDI inflows and financial development, although they revealed that financial development was a significant factor that lead to FDI (Al Nasser and Gomez 2009; Korgaonkar 2012; Desbordes and Wei 2014; Bayar and Ozel 2014; Fauzel 2016; Enisan 2017). On the contrary, a limited number of papers showed that FDI inflows have made significant contributions to the development of financial sectors (Abzari et al. 2011; Sahin and Ege 2015; Gebrehiwot et al. 2016). The relevant literature has generally focused on the impact of financial sector development on FDI inflows. This study investigates the impact of FDI inflows and portfolio inflows on the development of financial sectors as distinct from the existing literature.

In the related literature, there have been no studies which investigate the impact of FDI inflows on the development of financial sectors in the total sample of CEEU countries. However, some studies included several countries from the CEEU sample, and these studies generally revealed a significant relationship from financial development to FDI inflows (e.g., see Korgaonkar 2012; Desbordes and Wei 2014; Bayar and Ozel 2014).

Korgaonkar (2012) also analyzed the interaction between financial development and FDI inflows in 78 countries over the period from 1980-2009 utilizing a data mining approach and discovered financial development was an important prerequisite for the attraction of FDI inflows. Desbordes and Wei (2014) researched the relationship between FDI flows and financial development of both source and destination countries in 83 source countries with 3919 parent companies and 125 destination countries with 13 broad manufacturing sectors over the 2003-2006 period, employing panel regression and revealing that improvements in financial sectors of source and destination countries had positive impact on FDI flows.

Furthermore, Bayar and Ozel (2014) also explored the determinants of FDI inflows in seven EU transition economies during 1997-2011 and concluded that financial development positively affected FDI inflows. In another study, Sahin and Ege (2015) also examined the causal interaction between FDI inflows and financial development in Turkey, Macedonia, Greece and Bulgaria over the period from 1996-2012 using bootstrap causality tests and revealed a unilateral causality from FDI inflows to financial development in Bulgaria and Greece, but a two-way causality in Turkey.

Some papers researched the interplay between finance-FDI for different countries and country groups. In one of the initial studies, Al Nasser and Gomez (2009) studied the interplay among FDI inflows, banking, and capital market development in 15 countries from Latin America between 1978 and 2003 with panel regression and revealed a positive interaction among FDI inflows, banking sector, and capital market development. Furthermore, Anyanwu (2011) revealed that financial development affected FDI inflows negatively in the study about factors behind FDI inflows to Africa. In a similar way, Abzari et al. (2011) analyzed the causality between financial development and FDI inflows in eight developing countries between 1976-2005 using a Vector Autoregressive (VAR) model and reached a contrary one-way causality from FDI inflows to financial development.

Gebrehiwot et al. (2016) analyzed the connection between financial development and FDI in eight African countries between 1991-2013 employing Granger causality tests and panel regression and revealed a two-way causality between the variables. Bayar and Ozturk (2016) also examined the causal interaction between financial development and FDI inflows in Turkey over the 1974-2015 period with the bootstrap Granger causality tests of Hacker and Hatemi-J (2006) and determined a one-way causality from the development of financial sectors to foreign direct investment inflows. Fauzel (2016) 
also analyzed the relation between FDI and financial development in a small island developing states during the 1990-2013 period, using a panel vector autoregressive model and found a bi-causal relationship. Therefore, foreign investments contribute to countries' financial development, but that it also attracts and encourages foreign investment. Enisan (2017) investigated the major determinants underlying FDI inflows in Nigeria employing the Markov regime-switching approach and revealed that the development level of a financial sector is one of the main determinants for FDI attraction.

Finally, some researchers have studied the interplay between foreign capital inflows and capital market development and discovered a positive effect of FDI inflows and foreign portfolio investments on stock markets development (Raza et al. 2015; Abdul Malik and Amjad 2013; Evrim-Mandaci et al. 2013; Adam and Tweneboah 2009; Billmeier and Massa 2007; El-Wassal 2005; Claessens et al. 2001).

\section{Data and Econometric Methodology}

We conducted an empirical study that examined the cointegrating and causal relationship between financial development and FDI inflows in CEEU economies from 1996-2015 using the cointegration test of Westerlund-Durbin-Hausman (2008) and the causality test of Dumitrescu and Hurlin (2012).

\subsection{Data}

The annual data of domestic credit to private sector (\% of Gross Domestic Product (GDP)) was used in the model as proxy for financial sector development, because the banking sector is the locomotive of the financial sector in CEEU countries and was taken as a representative of financial development in many empirical studies (e.g., see Lane and McQuade 2013; Petkovski and Kjosevski 2014). Net inflows of foreign direct investment as a percent of GDP was taken as proxy for FDI inflows and foreign portfolio investments were taken as the control variable. The priod selected for this research was influenced by data availability for the following countries: Slovenia, Slovak Republic, Romania, Poland, Lithuania, Latvia, Hungary, Estonia, Czech Republic, Croatia, and Bulgaria. For econometric analysis we used the variables indicated in Table 1.

Table 1. Data description.

\begin{tabular}{ccc}
\hline Variable & Symbol & Data Source \\
\hline Domestic credit to private sector (\% of GDP) & DCRD & World Bank (2016b) \\
Foreign direct investment, net inflows (\% of GDP) & FDI & World Bank (2016c) \\
Portfolio Investment, net (\% of GDP) & PORTF & World Bank (2016a) \\
\hline
\end{tabular}

Source: own calculations.

The level of domestic credit to private sectors followed a horizontal trend in all sample countries until 2002, but sharp increases were seen in the variables between 2002 and 2010 possibly arising from the EU membership process. Contractions were then experienced in the volume of domestic credit to private sectors due to the global financial crisis and Eurozone sovereign debt crisis. On the other hand, the same pattern was seen in FDI inflows in the countries of the sample.

The study was conducted using the software packages Stata 14.0 (Lakeway Drive, College Station, TX, USA), EViews 9.0 (IHS Global Inc., 4521 Campus Drive, Irvine, CA, USA), and Gauss 11.0 (Aptech Systems, Inc., Chandler, AZ, USA). The descriptive statistics and correlation matrix of variables used in this research are presented in Table 2. The average of domestic credit to private sectors was $43.42 \%$ as a $\%$ of GDP in the overall panel during the study period, and the size of domestic credit to private sector as a \% of GDP was the highest in Croatia with a $65.47 \%$ and the lowest in Romania with a $29.89 \%$. The mean of net FDI inflows was about $5 \%$ in the overall panel during the study period, and negative net FDI values were experienced in Hungary, Latvia, and Slovenia in 2009, and in Hungary in 2010 during the global financial crisis and Eurozone sovereign debt crisis. The CEEU countries also experienced very volatile net portfolio inflows during the study period. 
Lastly, the correlation matrix revealed a positive correlation between domestic credit to private sectors, FDI net inflows, and net portfolio inflows.

Table 2. Descriptive statistics and the correlation matrix of the variables in the study.

\begin{tabular}{ccccc}
\hline Variables & Mean & Std. Dev. & Min & Max \\
\hline DCRD & 43.42487 & 20.81462 & 0.1858704 & 101.2876 \\
FDI & 5.028768 & 6.051212 & -16.09109 & 50.78472 \\
PORTF & -0.5416199 & 3.439216 & -12.81867 & 16.09195 \\
\hline \multicolumn{5}{c}{ Correlation Matrix } \\
\hline \multicolumn{5}{c}{ FDI } \\
DCRD & DCRD & PORTF \\
FDI & 0.0057913 & 0.057913 & 0.036609 \\
PORTF & 0.036609 & 0.237073 & 0.237073 \\
\hline \multicolumn{5}{c}{ Source: }
\end{tabular}

Source: own calculations.

\subsection{Econometric Model and Methodology}

The econometric model explored the impact of FDI and foreign portfolio inflows on the development of financial sector. In this context, the following model was established:

$$
D C R D=f(F D I, P O R T F)
$$

Theoretically, the impact of both FDI inflows and foreign portfolio inflows on the development of financial sector changes depends on the total of positive and negative effects. FDI inflows may affect the development of financial sectors positively by increasing funds in a financial system, but can also have no influence or a negative impact on the development of financial sectors because FDI inflows are also an alternative financing instrument. On the other side, foreign portfolio investments can contribute to the development of financial sectors by providing funds for financial markets through purchases of financial instruments, but considerable withdrawals in foreign portfolio inflows have the potential to damage financial institutions.

Cross-sectional dependency and homogeneity among the variables are important in econometric test selections used in the empirical analysis, such as panel unit root tests and cointegration tests.

The first step was to test cross-sectional independence among series using the Lagrange multiplier (LM) adjusted test provided by Pesaran et al. (2008), because the time dimension (T) $=20$ is higher than the cross-sectional dimension $(\mathrm{N})=11$. Ultimately, we tested homogeneity using delta tilde and adjusted delta tilde tests by Pesaran and Yamagata (2008).

The second step was to analyze the integration levels of the variables using the CIPS unit root test provided by Pesaran (2007) which regards cross-sectional dependency.

Further, based on the Westerlund (2008) cointegration test, we investigated long-run relationships among the variables because cross-sectional dependency was present in the econometric analysis of the dataset. The tests regards both cross-sectional dependency and heterogeneity, but dependent variable should be I(1) in order to use this test. The test also used a multiplicative correction to eliminate the effects of serial correlation, and therefore it was more computationally convenient than the residual-based tests of Pedroni (2004) and Westerlund (2008). The tests calculated two statistics: the Durbin-Hausman group statistic and the Durbin-Hausman panel statistic.

The Durbin-Hausman panel statistic assumes that the autoregressive parameters are homogeneous and is calculated as follows (Westerlund 2008):

$$
D H_{p}=\hat{S}_{n}(\widetilde{\varnothing}-\hat{\varnothing})^{2} \sum_{i=1}^{n} \sum_{t=2}^{T} \hat{e}_{i t-1}^{2}
$$


On the other hand, the Durbin-Hausman group statistic assumes that the autoregressive parameters are heterogeneous and is calculated as follows (Westerlund 2008):

$$
D H_{g}=\sum_{i=1}^{n} \widetilde{S}_{i}(\widetilde{\varnothing}-\hat{\varnothing})^{2} \sum_{t=2}^{T} \hat{e}_{i t-1}^{2}
$$

Finally, the causal interaction between foreign capital inflows and financial sector development was investigated using the causality test of Dumitrescu and Hurlin (2012), an improved form of the Granger (1969) non-causality test that regards heterogeneity.

\section{Empirical Analysis}

\subsection{Cross-Sectional Dependency and Homogeneity Tests}

The first step in our empirical analysis was to investigate cross-sectional independency among the series using an LM-adjusted test provided by Pesaran et al. (2008), and the results are shown in Table 3. The null hypothesis-there is cross-sectional independency-was rejected at a $1 \%$ significance level, because the $p$ value was found to be 0.0000 . Thus, we revealed a cross-sectional dependency among the series.

Furthermore, homogeneity was analyzed using delta tilde test and the adjusted delta tilde provided by Pesaran and Yamagata (2008).

Table 3. Results of cross-sectional dependence and homogeneity tests.

\begin{tabular}{|c|c|c|}
\hline \multicolumn{3}{|c|}{ Cross-Sectional Dependency Tests } \\
\hline Test & Statistic & $p$-Value \\
\hline LM (Breusch and Pagan (1980)) & 505.6 & 0.0000 \\
\hline LM adj * (Pesaran et al. (2008)) & 100.2 & 0.0000 \\
\hline LM CD * (Pesaran (2004)) & 16.39 & 0.0000 \\
\hline \multicolumn{3}{|c|}{ Homogeneity Tests } \\
\hline Test & Statistic & $p$-Value \\
\hline Delta_tilde & -0.478 & 0.684 \\
\hline Delta_tilde_adj & -0.532 & 0.702 \\
\hline
\end{tabular}

Results indicate that the null hypothesis—-there is homogeneity—was accepted and cointegrating coefficients are homogenous.

In light of the test results, we used the panel unit root test and cointegration test regarding the cross-sectional dependence.

\subsection{Panel Unit Root Tests}

The next step in our research was to apply the panel unit root test proposed by Maddala and Wu (1999) and the cross-sectional augmented IPS (CIPS) test (Im et al. 2003) proposed by Pesaran (2007) in order to analyze integration levels of the variables. While the Maddala and Wu (1999) test did not assume a cross-sectional dependency, the CIPS test took into consideration cross-sectional dependency. Findings presented in Table 4 indicate that FDI and PORTF are I(0), while DCRD is I(1). 
Table 4. Results of panel unit root tests.

\begin{tabular}{ccccc}
\hline & \multicolumn{2}{c}{ Maddala and Wu (1999) Panel Unit Root Test } & \multicolumn{2}{c}{ CIPS Panel Unit Root Test } \\
\hline Variables & Constant $(p$ Value) & Constant + Trend $(p$ Value) & Constant $(p$ Value) & Constant + Trend $(p$ Value $)$ \\
\hline DCRD & $19.401(0.620)$ & $9.048(0.993)$ & $1.188(0.883)$ & $2.636(0.996)$ \\
d(DCRD) & $41.736(0.007)^{* * *}$ & $29.806(0.003)^{* * *}$ & $-2.816(0.002)^{* * *}$ & $-3.387(0.000)^{* * *}$ \\
FDI & $53.584(0.000)^{* * *}$ & $47.053(0.001)^{* * *}$ & $-2.321(0.010)^{* * *}$ & $-1.879(0.030)^{* * *}$ \\
d(FDI) & $150.388(0.000)^{* * *}$ & $117.759(0.000)^{* * *}$ & $-5.784(0.000)^{* * *}$ & $-4.338(0.000)^{* * *}$ \\
PORTF & $85.763(0.000)^{* * *}$ & $54.302(0.000)^{* * *}$ & $-6.247(0.000)^{* * *}$ & $-5.119(0.000)^{* * *}$ \\
d(PORTF) & $182.056(0.000)^{* * *}$ & $135.458(0.000)^{* * *}$ & $-8.307(0.000)^{* * *}$ & $-6.381(0.000)^{* * *}$ \\
\hline
\end{tabular}

Note: ${ }^{* * *}$ significance at $1 \%$ level. Source: own calculations.

According to these results we selected the Westerlund-Durbin-Hausman (2008) cointegration test proposed to be used when variables have different integration levels.

\subsection{Westerlund-Durbin-Hausman (2008) Panel Cointegration Test}

Furthermore, we tested the long-run relationships among the series with different levels of integration using Durbin-Hausman tests, namely the Durbin-Hausman group test (based on panel heterogeneity) and the panel test of Durbin-Hausman (based on panel homogeneity), developed by Westerlund (2008). We considered these the most suitable cointegration tests based on the fact that the dependent variable was not $\mathrm{I}(0)$ and based on the presence of cross-sectional dependency. Compared with other panel cointegration tests, the Westerlund test admits the presence of cross-sectional dependency and independent series can be integrated at different orders.

Based on the Westerlund (2008) cointegration test, we analyzed the cointegrating relationships among variables. Results are presented in Table 5 . We considered panel statistics, based on the fact that our panel was homogenous and indicated the acceptance of the null hypothesis (there is no cointegration relationship) and no cointegrating relationship among the variables was identified.

Table 5. Results of the Westerlund-Durbin-Hausman (2008) cointegration test.

\begin{tabular}{ccc}
\hline Test & Statistic & $p$-Value \\
\hline Durbin-Hausman Group Statistic & 26.005 & 0.000 \\
Durbin-Hausman Panel Statistic & 0.388 & 0.349 \\
\hline
\end{tabular}

Source: Own calculation based on Westerlund-Durbin-Hausman (2008) cointegration test results.

The projection of the relevant theoretical literature is that FDI inflows can affect the development of financial sectors positively or negatively depending on the country's specific features. However, in this study there was no statistically significant relationship among financial development, FDI inflows, and foreign portfolio inflows. Thus, FDI inflows are not a significant factor behind the development of financial sectors in CEEU countries in the long run.

\subsection{Dumitrescu and Hurlin (2012) Panel Causality Test}

Using the Dumitrescu and Hurlin (2012) causality test we examined short-term causal relationships among financial development, FDI inflows, and foreign portfolio inflows series and the results are reported in Table 6.

The results demonstrate that there is a unidirectional causal relationship from the existing financial development to foreign development investment inflows based on the fact that the null hypothesis was rejected. So financial development has an important role in attraction of FDI inflows in the short run, but foreign portfolio investments have no significant influence on financial sector development. Our findings are consistent with the general trend in the relevant literature (e.g., see Korgaonkar 2012; Desbordes and Wei 2014; Bayar and Ozel 2014; Bayar and Ozturk 2016). Findings reveal that FDI 
inflows also had no significant influence in the short-run development of financial sector development, but financial development had a significant impact on the attraction of FDI flows in CEEU countries.

Table 6. Causality test results.

\begin{tabular}{cccc}
\hline Null Hypothesis & W-Stat. & Zbar-Stat. & Prob. \\
\hline FDI $\nrightarrow \Delta$ DDCRD & 1.94881 & 1.43223 & 0.1521 \\
$\Delta$ DDCRD $\nrightarrow$ FDI & 2.27263 & 2.01563 & $0.0438 * *$ \\
PORTF $\nrightarrow \Delta$ DDCRD & 0.75915 & -0.71109 & 0.4770 \\
$\Delta$ DDCRD $\nrightarrow$ PORTF & 0.97183 & -0.32793 & 0.7430 \\
PORTF $\nrightarrow$ FDI & 0.81806 & -0.59614 & 0.5511 \\
FDI $\nrightarrow$ PORTF & 1.55843 & 0.76274 & 0.4456 \\
\hline
\end{tabular}

Note: ${ }^{* *}$ Lag length was taken as 1 . Source: own calculations.

\section{Conclusions}

Accelerating globalization processes has caused considerable increases in flows of FDI and portfolio investments among countries as of the mid-1980s. Furthermore, many countries have experienced a remarkable development in their finance sectors together with financial liberalization, which is an important reflection of globalization processes. This research analyzed interactions between financial development, FDI inflows, and foreign portfolio inflows in CEEU countries during 1996-2015 using the Westerlund (2008) cointegration test and the Dumitrescu and Hurlin (2012) causality test. We discovered that there was no long-run relationship between financial development, FDI inflows, and foreign portfolio investment inflows. However, the causality analysis revealed that there was unidirectional causality from financial development to FDI inflows, but no causality from FDI inflows to financial development. On the other hand, foreign portfolio inflows had no significant impact on financial development. Therefore, FDI inflows had no significant impact on the development of financial sectors in both the short- and long-run, but financial development had significant effects on FDI inflows in CEEU countries, so our findings tend to strengthen the conclusions of Al Nasser and Gomez (2009); Korgaonkar (2012); Desbordes and Wei (2014); Bayar and Ozel (2014); Fauzel (2016); and Enisan (2017).

This paper concludes that a developed financial system leads a country to attract more FDI inflows, with provision of economically better external financing for multinational enterprises. Bayar and Ozel (2014) reached the same finding for the same sample and Korgaonkar (2012) and Desbordes and Wei (2014) found that a developed financial sector is an important prerequisite of FDI attraction for a panel consisting of many countries. However, we have revealed that FDI inflows had no significant effects on the development of financial sectors for this sample of countries, although a negative or positive impact can be seen theoretically. We evaluate that this can arise from the share of FDI inflows in terms of brownfield investments and the existence of a monetary union. In this context, Gebrehiwot et al. (2016) and Fauzel (2016) revealed a two-way interaction between finance and FDI. Further studies can be focused on concrete measures and actions that can be adopted by financial sectors in order to increase attraction of FDI inflows.

Author Contributions: All authors have contributed significantly to this research in all phases and sections.

Funding: This research received no external funding.

Conflicts of Interest: The authors declare no conflict of interest. 


\section{References}

Abdul Malik, Ihtisham, and Shehla Amjad. 2013. Foreign direct investment and stock market development in Pakistan. Journal of International Trade Law and Policy 12: 226-42. [CrossRef]

Abzari, Mehdi, Fatemeh Zarei, and Sharif Shekarchizadeh Esfahani. 2011. Analyzing the link between financial development and foreign direct investment among D-8 group of countries. International Journal of Economics and Finance 3: 148-56. [CrossRef]

Acaravci, Songul Kakilli, Ilhan Ozturk, and Ali Acaravci. 2009. Financial development and economic growth: Literature survey and empirical evidence from Sub-Saharan African countries. South African Journal of Economic and Management Sciences 12: 11-27. [CrossRef]

Adam, Anokye M., and George Tweneboah. 2009. Foreign direct investment and stock market development: Ghana's evidence. International Research Journal of Finance and Economics 26: 178-85.

Adeniyi, Oluwatosin, Abimbola Oyinlola, Olusegun Omisakin, and Festus O. Egwaikhide. 2015. Financial development and economic growth in Nigeria: Evidence from threshold modelling. Economic Analysis and Policy 47: 11-21. [CrossRef]

Adjasi, Charles, Joshua Abor, Kofi A. Osei, and Ernestine E. Nyavor-Foli. 2012. FDI and economic activity in Africa: The role of local financial markets. Thunderbird International Business Review 54: 429-39. [CrossRef]

Ahmad, Fayyaz, Muhammad Umar Draz, and Su-Chang Yang. 2016. Foreign portfolio inflows and economic growth: Evidence from ASEAN5. Actual Problems of Economics 179: 57-69.

Aitken, Brian J., and Ann E. Harrison. 1999. Do domestic firms benefit from direct foreign investment? Evidence from Venezuela. The American Economic Review 89: 605-18. [CrossRef]

Al Nasser, Omar M., and Xavier Garza Gomez. 2009. Do well-functioning financial systems affect the FDI flows to Latin America? International Research Journal of Finance and Economics 29: 60-75.

Alfaro, Laura, Areendam Chanda, Sebnem Kalemli-Ozcan, and Selin Sayek. 2004. FDI and economic growth: The role of local financial markets. Journal of International Economics 64: 89-112. [CrossRef]

Almfraji, Mohammad Amin, and Mahmoud Khalid Almsafir. 2014. Foreign direct investment and economic growth literature review from 1994 to 2012. Procedia-Social and Behvioral Sciences 129: 206-13. [CrossRef]

Anyanwu, John Chukwudi. 2011. Determinants of Foreign Direct Investment Inflows to Africa, 1980-2007. African Development Bank Group Working Paper Series, No 136. Abidjan: African Development Bank Group, Available online: https://www.afdb.org/fileadmin/uploads/afdb/Documents/Publications / WORKING\%20136\%20Determinants\%20Of\%20Foreign\%20Direct \%20Investment $\% 20$ Inflows $\% 20$ To \% 20Africa\%201980-2007\%20AS.pdf (accessed on 10 January 2018).

Aqeel, Anjum, Mohammed Nishat, and Faiz Bilquees. 2004. The determinants of foreign direct investment in Pakistan. The Pakistan Development Review 43: 651-64.

Basu, Parantap, and Alessandra Guariglia. 2007. Foreign direct investment, inequality, and growth. Journal of Macroeconomics 29: 824-39. [CrossRef]

Bayar, Yılmaz, and Hasan Alp Ozel. 2014. Determinants of foreign direct investment inflows in the transition economies of European Union. International Journal of Research in Commerce, Economics and Management 4: 49-53.

Bayar, Yimaz, and Omer Faruk Ozturk. 2016. Interaction between financial development and foreign direct investment inflows in Turkey. Paper presented at Scientific Cooperation for the Future in the Social Sciences, Usak, Turkey, September 22-23; pp. 35-42.

Billmeier, Andreas, and Isabella Massa. 2007. What Drives Stock Market Development in the Middle East and Central Asia-Institutions, Remittances, or Natural Resources? International Monetary Fund Working Papers, WP/07/157. Washington: International Monetary Fund. Available online: https:/ /www.imf.org/external/ pubs/ft/wp/2007/wp07157.pdf (accessed on 5 January 2018).

Breusch, Trevor Stanley, and Adrian Rodney Pagan. 1980. The Lagrange multiplier test and its applications to model specification in eeconometrics. Review of Economic Studies 47: 239-53. [CrossRef]

Cherif, Mondher, and Christian Dreger. 2016. Institutional determinants of financial development in MENA countries. Review of Development Economics 20: 670-80. [CrossRef]

Chowdhury, Murshed. 2016. Financial development, remittances and economic growth: Evidence using a dynamic panel estimation. Journal of Applied Economic Research 10: 35-54. [CrossRef] 
Claessens, Stijn, Daniela Klingebiel, and Sergio L. Schmukler. 2001. FDI and Stock Market Development: Complements or Substitutes? Available online: http:/ /www.iadb.org/WMSFiles/products/research/files / pubS-FDI-4.pdf (accessed on 23 December 2017).

Dãian, Mate. 2012. The Veil of Communism: An Analysis of Lifespan, GDP per Capita, Human Capital, and Agricultural Productivity in Eastern Europe. Stanford: Stanford University, Available online: https:/ / economics.stanford. edu/sites/default/files/publications/mateidaianhonorsthesis-2012.pdf (accessed on 27 December 2017).

De Mello, Luiz R., Jr. 1997. Foreign direct investment in developing countries and growth: A selective survey. The Journal of Development Studies 34: 1-34. [CrossRef]

Desbordes, Rodolphe, and Shang-Jin Wei. 2014. The Effects of Financial Development on Foreign Direct Investment. World Bank Group Policy Research Working Paper 7065. Washington: World Bank Group, Available online: https: / / openknowledge.worldbank.org/handle/10986/20515 (accessed on 15 December 2017).

Dumitrescu, Elena-Ivona, and Christophe Hurlin. 2012. Testing for Granger non-causality in heterogeneous panels. Economic Modelling 29: 1450-60. [CrossRef]

El-Wassal, Kamal A. 2005. Understanding the growth in emerging stock markets. Journal of Emerging Market Finance. 4: 227-61. [CrossRef]

Enisan, Akinlo A. 2017. Determinants of foreign direct investment in Nigeria: A Markov regime-switching approach. Review of Innovation and Competitiveness 3: 21-48.

Eschenbach, Felix. 2004. Finance and Growth: A Survey of the Theoretical and Empirical Literature. Tinbergen Institute Discussion Paper No. TI 2004-039/2. Amsterdam: Tinbergen Institute, Available online: http:/ /ssrn.com/ abstract=530123 (accessed on 11 December 2017).

Estrin, Saul. 1991. Yugoslavia: The Case of Self-Managing Market Socialism. Journal of Economic Perspectives 5: 187-94. [CrossRef]

Evrim-Mandaci, Pınar, Bora Aktan, Guluzar Kurt Gumus, and Manuela Tvaronavičienè. 2013. Determinants of stock market development: evidence from advanced and emerging markets in a long span. Business: Theory and Practice 14: 51-56.

Fauzel, Sheereen. 2016. Modeling the Relationship between FDI and Financial Development in Small Island Economies: A PVAR Approach. Theoretical Economics Letters 6: 367-75. [CrossRef]

Forte, Rosa, and Rui Moura. 2010. The Effects of Foreign Direct Investment on the Host Country Economic Growth-Theory and Empirical Evidence. School of Economics and Management of the University of Porto (FEP) Working Paper, No. 390. FEP. Available online: http:/ / www.fep.up.pt/investigacao/workingpapers/ 10.11.02_wp390.pdf (accessed on 13 December 2017).

Gebrehiwot, Aklilu, Naser Esfahani, and Mustafa Sayin. 2016. The relationship between FDI and financial sector development: The case of sub-Saharan African region. International Journal of Regional Development 3: 64-80.

Gerschewski, Stephan. 2013. Do Local Firms Benefit from Foreign Direct Investment? An Analysis of Spillover Effects in Developing Countries. Asian Social Science 9: 67-76. [CrossRef]

Gorbunova, Yulia, Davide Infante, and Janna Smirnova. 2012. New Evidence on FDI Determinants: An Appraisal over the Transition Period. Prague Economic Papers 2: 129-49. [CrossRef]

Granger, C. J. 1969. Investigating causal relationships by econometrics models and cross spectral methods. Econometrica 37: 425-35. [CrossRef]

Hacker, R. Scott, and Abdulnasser Hatemi-J. 2006. Tests for causality between integrated variables using asymptotic and bootstrap distributions: Theory and application. Applied Economics 38: 1489-500. [CrossRef]

Huang, Yongfu. 2011. Determinants of Financial Development. London: Palgrave Macmillan UK.

Im, Kyung So, M. Hashem Pesaran, and Yongcheol Shin. 2003. Testing for unit roots in heterogeneous panels. Journal of Econometrics 115: 53-74. [CrossRef]

Kathuria, Vinish. 2000. Productivity spillovers from technology transfer to Indian manufacturing firms. Journal of International Development 12: 343-69. [CrossRef]

Kaur, Manpreet, Surendra S. Yadav, and Vinayshil Gautam. 2013. Financial System Development and Foreign Direct Investment: A Panel Data Study for BRIC Countries. Global Business Review 14: 729-42. [CrossRef]

Korgaonkar, Chaitanya. 2012. Analysis of the impact of financial development on foreign direct investment: A data mining approach. Journal of Economics and Sustainable Development 3: 70-78.

Kurtishi-Kastrati, Selma. 2013. The effects of foreign direct investments for host country's economy. European Journal of Interdisciplinary Studies 5: 26-38. 
Lane, Philip R., and Peter McQuade. 2013. Domestic Credit Growth and International Capital Flow. European Central Bank Working Paper Series, No. 1566. Frankfurt: European Central Bank.

Law, Siong Hook, and Muzafar Shah Habibullah. 2009. The determinants of financial development: Institutions, openness and financial liberalisation. South African Journal of Economics 77: 45-58. [CrossRef]

Levine, Ross. 1997. Financial development and economic growth: Views and agenda. Journal of Economic Literature 35: $688-726$.

Lipsey, Robert E. 2002. Home and Host Country Effects of FDI. NBER Working Paper. No. 9293. Chicago: University of Chicago Press, Available online: http:/ / www.nber.org/chapters/c9543.pdf (accessed on 27 December 2017).

Maddala, Gangadharrao S., and Shaowen Wu. 1999. A comparative study of unit root tests with panel data and new simple test. Oxford Bulletin of Economics and Statistics 61: 631-52. [CrossRef]

Mahmoodi, M., and E. Mahmoodi. 2016. Foreign direct investment, exports and economic growth: Evidence from two panels of developing countries. Economic Research Ekonomska Istrazivanja 29: 938-49. [CrossRef]

Maxim, Laura Diaconu. 2015. The dynamics of the FDI inflows during the last three decades. A comparative analysis between developing and developed countries. Revista Economica 67: 46-62.

Nistor, Ioan-Alin, and Dragos Păun. 2013. Taxation and its effect on foreign direct investments-The case of Romania. Financial Sciences 3: 37-47.

Noble, Thomas FX, Barry Strauss, Duane Osheim, Kristen Neuschel, and Elinor Accampo. 2011. Western Civilization: Beyond Boundaries, 6th ed. Boston: Cengage Learning, vol. 2.

Nwaogu, Uwaoma G., and Michael J. Ryan. 2015. FDI, foreign aid, remittance and economic growth in developing countries. Review of Development Economics 19: 100-15. [CrossRef]

Pedroni, Peter. 2004. Panel cointegration: Asymptotic and finite sample properties of pooled time series tests with an application to the PPP hypothesis. Econometric Theory 20: 597-625. [CrossRef]

Pesaran, M. Hashem. 2004. General Diagnostic Tests for cross Section Dependence in Panels. CESifo Working Papers No. 1233. Munich: CESifo, pp. 255-60.

Pesaran, M. Hashem. 2007. A simple panel unit root test in the presence of cross-section dependence. Journal of Applied Econometrics 22: 265-312. [CrossRef]

Pesaran, M. Hashem, and Takashi Yamagata. 2008. Testing slope homogeneity in large panels. Journal of Econometrics 142: 50-93. [CrossRef]

Pesaran, M. Hashem, Aman Ullah, and Takashi Yamagata. 2008. A bias-adjusted LM test of error cross-section independence. Econometrics Journal 11: 105-27. [CrossRef]

Petkovski, Mihail, and Jordan Kjosevski. 2014. Does banking sector development promote economic growth? An empirical analysis for selected countries in Central and South Eastern Europe. Economic Research-Ekonomska Istraživanja 27: 55-66. [CrossRef]

Popescu, Gheorghe H. 2014. FDI and Economic Growth in Central and Eastern Europe. Sustainability 6: 8149-63. [CrossRef]

Pradhan, Rudra P., Mak B. Arvin, John H. Hall, and Mahendhiran Nair. 2016. Innovation, financial development and economic growth in Eurozone countries. Applied Economics Letters 23: 1141-44. [CrossRef]

Raza, Syed Ali, Syed Tehseen Jawaid, Sahar Afshan, and Mohd Zaini Abd Karim. 2015. Is stock market sensitive to foreign capital inflows and economic growth? Evidence from Pakistan. Journal of Chinese Economic and Foreign Trade Studies 8: 142-64. [CrossRef]

Sahin, Serkan, and Ilhan Ege. 2015. Financial development and FDI in Greece and neighboring countries: A panel data analysis. Procedia Economics and Finance 24: 583-88. [CrossRef]

Saini, Neha, and Monica Singhania. 2018. Determinants of FDI in developed and developing countries: A quantitative analysis using GMM. Journal of Economic Studies 45: 348-82. [CrossRef]

Simionescu, Mihaela. 2016. The relation between economic growth and foreign direct investment during the economics crisis in the European Union. Zbornik radova Ekonomskog fakulteta u Rijeci: časopis za ekonomsku teoriju i praksu 34: 187-213. [CrossRef]

Smarzynska Javorcik, Beata. 2004. Does foreign direct investment increase the productivity of domestic firms? In search of spillovers through backward linkages. The American Economic Review 94: 605-27. [CrossRef]

UNCTAD. 2016. World Investment Report 2016. New York: United Nations Publication, Available online: http: / / unctad.org/en/pages/PublicationWebflyer.aspx?publicationid=1555 (accessed on 28 December 2017).

Uvalic, Milica. 2018. The Rise and Fall of Market Socialism in Yugoslavia. Available online: https:/ / doc-research. org/en/rise-fall-market-socialism-yugoslavia/ (accessed on 3 January 2018). 
Voghouei, Hatra, M. Azali, and Mohammad Ali Jamali. 2011. A survey of the determinants of financial development. Asian-Pacific Economic Literature 25: 1-20. [CrossRef]

Wan, Xueli. 2010. A literature review on the relationship between foreign direct investment and economic growth. International Business Research 3: 52-56. [CrossRef]

Westerlund, Joakim. 2008. Panel cointegration tests of the Fisher effect. Journal of Applied Econometrics 23: 193-223. [CrossRef]

World Bank. 2016a. Portfolio Equity, Net Inflows (BoP, Current US\$). Available online: http:/ / data.worldbank. org/indicator/BX.PEF.TOTL.CD.WD (accessed on 5 December 2017).

World Bank. 2016b. Domestic Credit to Private Sector (\% of GDP). Available online: http:/ / data.worldbank.org/ indicator/FS.AST.PRVT.GD.ZS (accessed on 5 December 2017).

World Bank. 2016c. Foreign Direct Investment, Net Inflows (\% of GDP). Available online: http:/ / data.worldbank. org/indicator/BX.KLT.DINV.WD.GD.ZS (accessed on 5 December 2017).

Žilinskè, Asta. 2010. Negative and positive effects of foreign direct investment. Economics and Management 15: 332-36.

(c) 2018 by the authors. Licensee MDPI, Basel, Switzerland. This article is an open access article distributed under the terms and conditions of the Creative Commons Attribution (CC BY) license (http://creativecommons.org/licenses/by/4.0/). 